\title{
Chapter 15 \\ Foreign Direct Investment and the Poverty \\ Reduction Nexus in Southeast Asia
}

\author{
Nathapornpan Piyaareekul Uttama
}

\begin{abstract}
This study attempts to empirically investigate the determinants of foreign direct investment (FDI) and related factors on Association of the Southeast Asian Nations's (ASEAN) poverty reduction, and focuses on spatial quantitative empirical evidence available on the ASEAN region. The spatial specification model is constructed and estimated by using the spatial panel data model technique. It is empirically estimated on the basis of a crucial assumption that the individual-country factors such as globalization factors, financial factors, political factors, and infrastructure factors and spatial FDI affect poverty reduction in ASEAN. Data at the country level for ASEAN-6 during the period 1995-2011 are collected from World Data Bank and International Country Risk Guide (ICRG). The analyses confirm the positive significant relationship between FDI inflows and poverty reduction in ASEAN in both individual and spatial aspects. Nevertheless, this relationship is significantly different between other factors and poverty reduction in ASEAN. For instance, while the relationship remains positive and significant for GDP growth, openness, and foreign debt in ASEAN, it is significant negative for financial and infrastructure factors, and ambiguous for political factor. Our results are also robust to alternative model specifications. The study concludes that FDI is conducive to poverty reduction. It supports the notion that regional value chain enhancement on FDI flows is beneficial for this region. Providing a poverty model of spatial FDI to researchers, the study presents results that are beneficial to business sectors and policy makers who are related to the investment in ASEAN.
\end{abstract}

Keywords Foreign direct investment - Poverty - ASEAN - Spatial panel data model

N.P. Uttama $(\triangle)$

Economics Program, School of Management, Mae Fah Luang University, Chiang Rai, Thailand

e-mail: nathapornpan@mfu.ac.th 


\subsection{Introduction}

The 2003 ASEAN Economic Community (AEC) declaration outlined the key characteristics of the Association of the Southeast Asian Nations (ASEAN) to be reached by 2015. Importantly, the achievement of these goals will lead ASEAN to human development and equitable economic development. This is in accordance with the declaration of the 2000 Millennium Development Goals (MDGs) of the United Nations that aims to contribute to human development and poverty reduction in developing countries by 2015. In order to lift ASEAN's population out of poverty, one mechanism, as defined in the AEC roadmap, was to promote foreign direct investment (FDI) in this region through the 2009 ASEAN Comprehensive Investment Agreement (ACIA). At a closer look, there seems to exist a positive linkage between FDI increase and poverty reduction. This is confirmed by the ASEAN statistics and the United Nations Development Programme (UNDP) report of 2013 (Fig. 15.1). FDI inflows to ASEAN from 2009 and 2011 have increased by $143 \%$ to $\$ 114.11$ billion (ASEAN Secretariat 2013). It is believed that a large number of foreign investors to ASEAN have appeared owing to the extension of ASEAN's external relations such as the Regional Comprehensive Economic Partnership endorsed on November 2011. Poverty reduction proxied by the Human Development Index (HDI) in all ASEAN member countries improved during 2009-2012 (United Nations Conference on Trade and Development 2013). The more successful the ACIA is, the more poverty reduction there is in ASEAN. Despite this apparent linkage, some questions remain on the impacts of other factors on poverty reduction in the ASEAN region, especially globalization factors. Therefore, poverty reduction through the trade and investment liberalization policy continues to be an issue that receives considerable attention among governments and researchers, especially policy makers in the ASEAN.

Currently, the studies on FDI and poverty reduction are large and still growing. These mainly deal with three problems: whether FDI inflows tend to increase or decrease poverty over time (Tsai and Huang 2007; Reiter and Steensma 2010; Gohou and Soumaré 2012; Jalilian and Weiss 2002), the impact of FDI and related factors on poverty (Akanbi and Du Toit 2011; Nissanke and Thorbecke 2010; Wade 2004; Nissanke and Thorbecke 2006; Zaman and Khilji 2013; Adams and Page 2005; Topalova 2010; Das 2009), and the strategies for reducing poverty (Kolk and van Tulder 2006; Fritzen 2002). Most findings have indicated statistically significant effects of globalization factors on poverty reduction. Though there are a number of studies on the impact of FDI and other related factors on poverty reduction, most have investigated poverty reduction from the entry of FDI as an individual-country factor. The existing empirical work, therefore, seems to ignore the insights into the role of spatial FDI effect on poverty reduction. Spatial FDI is concerned with the outcome of FDI inflows within a geographically bounded region. The significance of the spatial factors underlying FDI flows to ASEAN is still unclear as are the strategic approaches for reducing poverty in the region. 

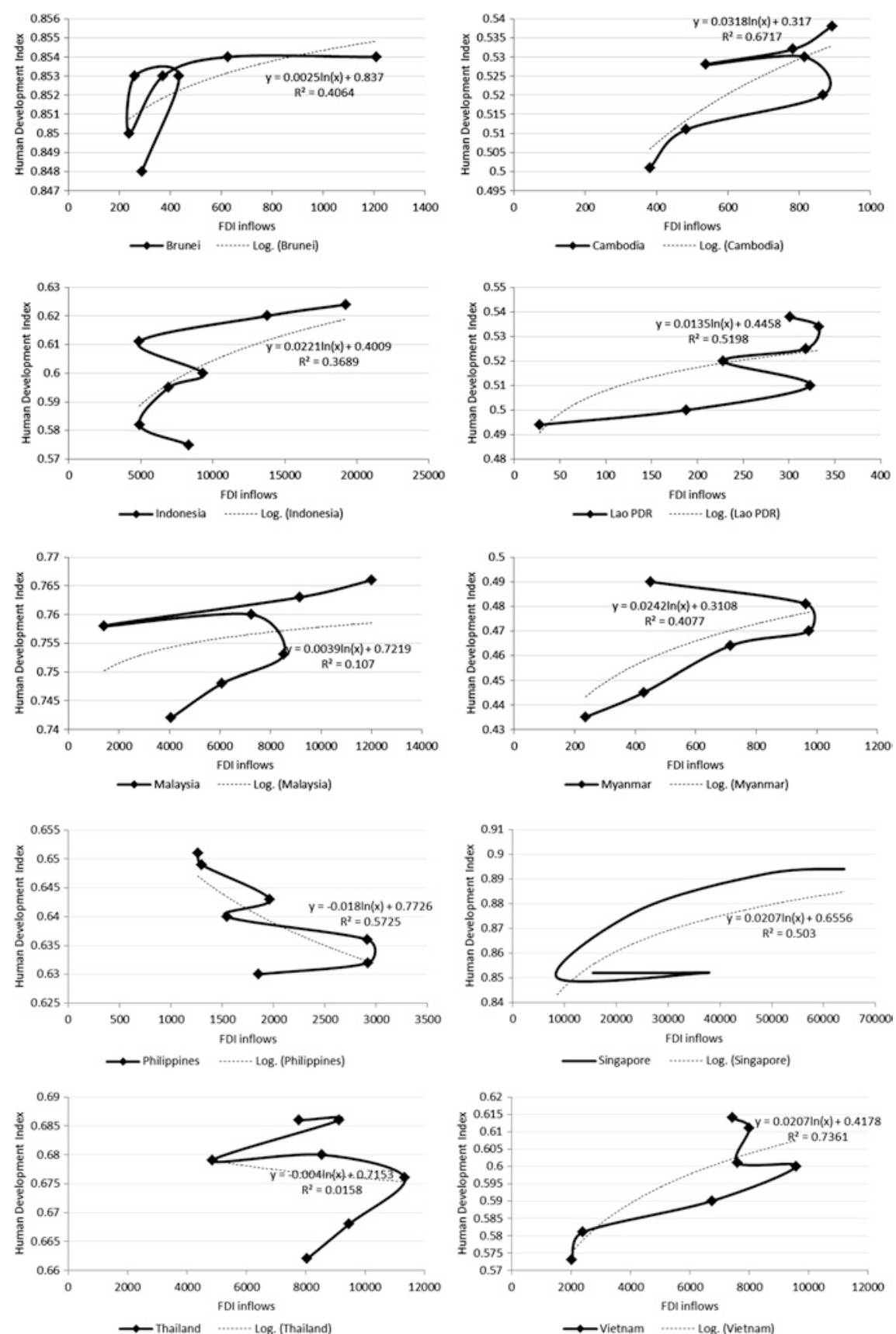

Fig. 15.1 The linkage between FDI inflows and Human development index in ASEAN, 20052011 (World Bank 2013; United Nations Conference on Trade and Development 2013) 
This study focuses on the determinants of individual-country factors and the spatial FDI effect on poverty reduction in ASEAN. The spatial specification model will be constructed and estimated using the spatial panel data model technique. It is empirically estimated on the basis of a crucial assumption that the individualcountry factors such as globalization factors, financial factors, political factors, infrastructure factors, and spatial FDI affect poverty reduction in ASEAN. Data at the country level for six ASEAN member countries (Indonesia, Malaysia, Philippines, Singapore, Thailand, and Viet Nam) during the period 1995-2011 were collected from the World Data Bank and ICRG. From the estimation results, we contribute to the how public policies can be aimed at tackling poverty reduction by attracting foreign investors to ASEAN. Finally, this research will provide a poverty model of spatial FDI to researchers. The survey results and policy guidance will be beneficial to business sectors and policy makers who are related to the investment in ASEAN. Particularly, the ASEAN economic agreements and policies should be tailored, integrated, and harmonized in order to achieve the desired outcome of becoming an $\mathrm{AEC}$, and to foster the sustainable and equitable economic development in ASEAN.

\subsection{Overview of FDI and Poverty}

This section focuses attention on the relevant linkage of FDI and poverty reduction in ASEAN through the ASEAN Comprehensive Investment Agreement and gives a brief literature review on FDI and poverty.

\subsubsection{The Stylized Facts of FDI and Poverty in ASEAN}

Southeast Asia is widely regarded as having sprung up as a region since the 2003 AEC declaration. The AEC blueprint outlined the four key characteristics to be reached by 2015: (a) a single market and production base, (b) a highly competitive economic region, (c) a region of equitable economic development, and (d) a region fully integrated into the global economy (ASEAN Secretariat 2008: p. 6). The success of AEC is highly dependent upon the achievement of implementing ASEAN's economic agreements. For instance, the dynamic growth effect from implementing the AEC roadmap has resulted in the growth achieved through FDI inflows to ASEAN during 2003-2010. This has been seen as highly desirable (ASEAN Secretariat 2013) and is often viewed as a model of 'inclusive growth.' Indeed, the ACIA is regarded as one of the drivers advancing inclusive growth in ASEAN. It was signed in 2009 and accredited the accession of ASEAN investors and foreignowned ASEAN-based investors into 'a more liberal, facilitative, transparent and competitive investment destination' (ASEAN Secretariat 2009: p. 3). Moreover, there is growing evidence that in the last decade, poverty in ASEAN economies has been substantially reducing as part and parcel of the AEC roadmap. Despite the growing investment priority given to the success of the AEC through the 
ACIA, there exists a notable gap in the understanding of the distributive impacts of FDI on ASEAN's poverty reduction as a whole. Hence, it is critically important to examine the mechanisms at work in the FDI-poverty nexus in ASEAN.

Figure 15.1 depicts the relevant linkage of ASEAN's FDI inflows and human development index during the period 2005 and 2011. The $x$ axis, FDI inflows, shows the ability in attracting FDI, while the y axis, human development index, measures the degree of poverty reduction. The figure indicates that an increase in FDI inflows has a statistically positive effect on poverty reduction at the same rate in almost ASEAN member countries, except for the Philippines and Thailand. Singapore dominates the scenario, having a steadily upward trend of FDI and poverty reduction. Singapore's ability in attracting FDI has improved as compared with other ASEAN members as has her ability in maintaining the quality of life represented by a higher income per capita.

Meanwhile, Indonesia, Malaysia, and Cambodia have exhibited a positive linkage between FDI and poverty reduction, except for the crisis period (2008-2009). The national economic development plan was one of the key factors for the success in poverty reduction in these countries, apart from the successful implementation of ACIA. The Malaysian New Economic Model launched in 2010, aimed at making Malaysia a high-income and quality country by 2020, played an important role in FDI inflows to Malaysia and poverty reduction. Likewise, Indonesia and Cambodia established the national economic development plan to accelerate economic growth and to reduce poverty rapidly. Even though Lao PDR and Viet Nam expressed a small positive relationship between FDI and poverty reduction, poverty reduction was improved.

After the economic reforms through the adoption of the 'Doi Moi' policy, FDI inflows to Viet Nam recorded significantly higher during 2007-2011, but the degree of poverty reduction was still quite small. This was the same situation that Lao PDR had confronted. Thus, both economies have to accelerate the implementation of the ACIA and their own national development plan, which is aimed at sustainable economic growth, social development, and poverty reduction. Finally, surprisingly, the Philippines and Thailand showed a negative linkage between FDI and poverty reduction in the recent years. It is implied that the level of poverty in the Philippines and Thailand tended to reduce owing to factors other than FDI inflows. Despite the presence of unrelated results of the implementation of the ACIA and poverty reduction, it was still believed that FDI inflows could lead to economic growth and poverty reduction, as seen by the high growth of inward FDI in the ASEAN during the last two decades. Even though the experience of the success of the ACIA in the past year can be an indication on the future of the ASEAN, ASEAN still fights hard to achieve the goals of the AEC.

\subsubsection{Literature Review}

The poverty perspective is a delicate subject. Currently, numerous studies have estimated the impacts on poverty reduction in many contexts, for instance, how 
change in poverty takes place over time; how poverty reduction is affected by economic growth, socioeconomic development, and globalization; and how poverty is reduced across countries. Most of these studies provided a solid foundation for further studies in different regions in the world. In this section, we focus on the literature on the globalization-poverty-reduction nexus.

First, let us introduce the literature on the FDI-poverty nexus. The existing studies on the linkage of FDI and poverty reduction indicate that FDI inflows tend to increase or decrease poverty over time. In fact, there are a large number of empirical studies supporting the positive linkage of FDI and poverty reduction. For instance, Gohou and Soumaré (2012) examined the impact of FDI on poverty reduction through welfare improvement in the African region. Using panel regression analysis, they found a strongly positive relationship between FDI and welfare improvement at the level of Africa as a whole. They also found that FDI has a higher impact on poverty reduction in poorer African countries than the wealthier ones. Reiter and Steensma (2010) mainly determined the impact of FDI policy and corruption on human development. They found that FDI inflow decreased HDI improvement owing to the absence of discriminatory FDI policies and the presence of corruption. Jalilian and Weiss (2002) indicated that FDI has a close relation between average income growth and growth of the income of the poor (proxy for poverty reduction) in ASEAN. They employed the panel data technique to estimate the FDI-growth-poverty relation. However, there was little evidence on the negative relation between FDI and poverty reduction. For example, Tsai and Huang (2007) analyzed the impacts of economic growth, openness, and the role of government on poverty alleviation in Taipei,China. Using the time series technique, the estimated results showed that inward FDI has no significant impact on the income of the poor in Taipei,China, whereas sustained economic growth and trade openness are the major driving forces for poverty reduction.

Second, we discuss the studies on how poverty reduction is affected by economic growth, socioeconomic development, and globalization. Akanbi and Du Toit (2011) developed a comprehensive full-sector macroeconometric model with the aim of examining how poverty reduction is affected by economic growth in Nigeria. Using the Engle-Granger two-step co-integration technique, their findings confirmed the growth-poverty divergence in Nigeria. They also suggested that the quality of government spending will lead to sustainable economic growth and that it eventually results in the improvement of people's standard of living and poverty reduction. Likewise, Zaman and Khilji (2013) determined the interrelationship between growth-inequality-poverty and pro-poor growth policies in Pakistan at the rural, urban, and national levels. Using the Household Income and Expenditure Survey (HIES) and the Pakistan Integrated Household Survey (PIHS) data, the results showed the negative relation between growth and poverty in rural, urban, and national levels as a key factor of the poverty reduction. They also indicated that degree of employment intensity, employment opportunities, tariffs, exchange rate and taxation policies are important to poverty reduction. Employing a globalization-poverty perspective, Nissanke and Thorbecke (2006, 2010) examined the impacts of globalization (e.g., trade and technological openness, 
migration and mobility, and pro-poor institutions) on poverty reduction. Their findings were not conclusive, that is, the change in globalization could lead to poverty and poverty reduction. However, the studies of Topalova (2010), Das (2009), Adams and Page (2005) and Wade (2004) support the important role of globalization on poverty reduction. For instance, Topalova (2010) examined the impact of trade openness on poverty reduction in India. Using the panel data model technique, his estimated results showed that a larger reduction in tariff protection (proxy for trade openness) dramatically declines poverty in rural and urban India. The findings of Das (2009), Adams and Page (2005) and Wade (2004) pointed out that globalization, trade, and international migration and remittances significantly reduce the level of poverty.

Third, we look at the studies of Kolk and van Tulder (2006) and Fritzen (2002) that investigated the strategy for reducing poverty. The former developed a framework to analyze FDI policies, using the poverty issues outlined by international organizations. They found that the FDI policies are aimed at alleviating the poverty. Moreover, inter-regional and intra-regional investment also boost economic growth and development (Chen and Groenewold 2013; Ouyanga and Fub 2012; Fukaoa et al. 2003). The latter stated that the achievement of policy reform in Viet Nam through fostering a market-driven and pro-poor policy resulted in poverty reduction.

Apart from the studies discussed, there are many other studies on factors influencing FDI that may be indirectly related to poverty. Particularly, the pollution haven hypothesis indicates the linkage between the relocation of multinational firms and the country's level of environmental standards, which can lead to the possibility of poverty traps arising from market failure. Indeed, there is scarce evidence on the pollution havens and poverty. The empirical results of Rezza (2013) and Smarzynska and Wei (2001) confirmed that the entry of FDI is related to a country's weak environmental standards. However, Pao and Tsai (2011) determined the relation between pollution emission, energy consumption, FDI, and GDP. They found that the way to promote FDI is environmental protection through coordinated know-how and technological transfers with foreign companies.

In sum, most empirical studies indicate the statistically significant effects of globalization factors on poverty reduction. The empirical analysis in this study is conducted under the specific hypotheses based on the literature review mentioned above.

\subsection{Empirical Approach}

\subsubsection{Empirical Model}

This paper attempts to construct the specification model in the light of the literature review for investigating factors that influence poverty reduction. In fact, there are various parameters to measure poverty reduction such as poverty headcount ratio and poverty gap. However, some argue that such indexes do not reflect 
deprivation in human development (Fosu 2007). The UNDP constituted the human development index (HDI) to represent a more in-depth and sustainable poverty reduction perspective that takes into account life expectancy, education, and standard of living. In addition, HDI is an indicator for achieving the MDGs (United Nations Conference on Trade and Development 2013). Hence, in this study, the human development index is regarded as a proxy for poverty reduction. The wellsuited model specification to capture the empirical impacts of economic factors, globalization factors, financial factors, political factors, infrastructure factors, and spatial FDI effect on ASEAN's poverty reduction is shown in the following threshold specification:

$$
\begin{aligned}
\mathrm{HDI}_{i t}= & \beta_{0}+\beta_{1} \mathrm{ECON}_{i t}+\beta_{2} \mathrm{GLOBAL}_{i t}+\beta_{3} \mathrm{FIN}_{i t}+\beta_{4} \mathrm{POL}_{i t}+\beta_{5} \mathrm{INFRA}_{i t} \\
& +\alpha_{1} \mathrm{WHDI}_{i t}+\alpha_{2} \mathrm{WFDI}_{i t}+u_{i t}
\end{aligned}
$$

The dependent variable, HDI, denotes the poverty reduction in host country $i$ at year $t$ where $i$ includes Indonesia, Malaysia, the Philippines, Singapore, Thailand, and Viet Nam; $t=1, \ldots, T$ and $T$ is 17 years (1995-2011). The independent variables are divided into six categories: economic factors (ECON), globalization factors (GLOBAL), financial factors (FIN), political factors (POL), infrastructure factors (INFRA), and spatial effects. ECON is expressed as GDP per person employed (GDPEMP), inflation (INF), real exchange rate (RER), and index of economic freedom (IEF), whereas GLOBAL is expressed as the percentage share of FDI inflows in GDP (FDI), terms of trade (TOT), and regional economic integration proxied by openness index (OPEN). FIN is expressed as the percentage share of domestic credit in the private sector (the PRC), the percentage share of market capitalization in GDP (CAP), current account balance (CA), and debt service on external debt (FDEBT). POL is expressed as government stability (GE), bureaucracy quality (RQ), and law and order (RL). INFRA is expressed as the amount of goods transported by roads (ROAD), the amount of goods transported by railways (RAIL), the number of container port traffic (PORT), and the air transport registered carrier departures worldwide (AIR). All variables are in natural logarithms.

Moreover, our model specification also allowed for a model with spatial dependence across spatial units at each point in time. In other words, the spatialweighted independent variables are incorporated into the empirical model in order to consider the presence/absence of spatial autocorrelation. It is a so-called spatial model with spatially correlated residual (Anselin 1999). WHDI and WFDI are the spatial lagged variables of poverty reduction and FDI, which are introduced to capture the economic geographic relationship among countries (spatial units). They are represented by spatially weighted averages, based on the distance between the capitals of ASEAN member countries. This generates the spatially weighting matrix $W_{N}$ which is $N_{t} x N_{t}$, where $N$ is the number of cross-sectional units that is row-normalized with typical elements $w_{i j}=d_{i j}^{-1} / \sum_{j=1}^{N}\left(d_{i j}^{-1}\right)$ if $i \neq j$ and $w_{i j}=0$ if $i=j$ (based on Baltagi et al. 2007). The error term $\left(u_{i t}\right)$ is assumed to be $u_{t}=\rho W_{N} u_{t}+\varepsilon_{t}$ with $|\rho|<1$, where $\varepsilon_{i t}=\mu_{i t}+v_{i t}$. The term $\mu_{i t}$ refers to country effects to be control for time-invariant heterogeneity effects. The term $v_{i t}$ 
is classical error assumed to be uncorrelated over all $i$ and $t$. The term $\rho$ is a coefficient on the spatially correlated errors measuring the effect of third-country observations on the dependent variable. The $|\rho|=0$ implies that the disturbances are not spatially correlated.

In order to obtain concrete empirical results, diagnostic tests are first conducted to choose an appropriate estimator and to define the quality of the empirical model. First, the Moran's I test is used to check the spatial autocorrelation in residuals. The presence of spatial autocorrelation causes misspecification and measurement errors (Anselin 1999, 2001). Ignoring spatially correlated errors leads to a problem of efficiency that the coefficient standard error estimates are biased, but the coefficient estimates remain unbiased. Second, the BreuschPagan test is used to detect the misspecification in terms of heteroskedasticity. Ignoring the presence of heteroskedasticity could result in a biased variance of the estimated parameters and misleading conclusions, but it does not result in biased parameter estimates (Wooldridge 2001). Third, the Jarque-Bera test is used to check the quality of the estimated model or the normality. Fourth, the variance inflation factor test is used to check multicollinearity in order to ensure a precision of predictions in a multiple regression model. In practice, a VIF greater than 10 indicates a presence of multicollinearity, whereas a VIF greater than 30 becomes potentially problematic, requiring specific corrections (Kennedy 2003). Finally, the spatial panel data model with Maximum Likelihood estimator [both fixed effect model (FEM) and random effect model (REM) estimator] is empirically applied to indicate the impacts of FDI and related factors, and the spatial effects on poverty reduction. The estimated results are computed on a mathematical program and simultaneously interpreted with the qualitative results.

\subsubsection{Data Source}

The data set consists of cross-country observations for six ASEAN member countries (Indonesia, Malaysia, the Philippines, Singapore, Thailand, and Viet Nam) during the period 1995-2011. Almost all variables are extracted from the World Development Indicators. The variables proxies for political factors, government stability, bureaucratic quality, and law and order are taken from the ICRG of the PRS Group. Table 15.1 exhibits the descriptive statistics.

\subsection{Empirical Results}

The empirical results of the impacts of FDI, related factors, and spatial effects on ASEAN's poverty reduction are presented in this section. In the spatial panel data estimation, the estimated results are provided in six different model aspects. 
Table 15.1 Descriptive statistics

\begin{tabular}{l|l|l|l|l}
\hline Bilateral variables & Mean & Standard deviation & Minimum & Maximum \\
\hline HDI & -0.3699 & 0.1567 & -0.5568 & 0.0000 \\
\hline GDPEMP & 9.5512 & 0.7332 & 8.4765 & 10.8258 \\
\hline INF & 1.4148 & 0.8724 & -0.8554 & 3.1405 \\
\hline RER & 3.8523 & 1.7447 & 0.0000 & 4.7333 \\
\hline IEF & 4.1339 & 0.2286 & 3.6532 & 4.4750 \\
\hline FDI & 1.2495 & 1.1544 & -0.2870 & 3.3272 \\
\hline TOT & 10.2713 & 13.4291 & 0.0000 & 31.4274 \\
\hline OPEN & 4.9366 & 0.6640 & 3.8179 & 6.1322 \\
\hline The PRC & 4.2022 & 0.6292 & 3.2029 & 4.9424 \\
\hline CAP & 4.0343 & 1.0437 & -0.1372 & 5.5466 \\
\hline CA & 1.1364 & 1.6401 & -3.7072 & 3.3037 \\
\hline FDEBT & 2.9372 & 1.3512 & 0.0000 & 4.0969 \\
\hline GE & -0.4424 & 0.2716 & -0.6931 & 0.0000 \\
\hline RQ & -0.3072 & 0.1658 & -0.6061 & 0.0000 \\
\hline RL & -0.5728 & 0.2633 & -0.8754 & -0.1823 \\
\hline ROAD & 1.5432 & 2.1033 & 0.0000 & 4.6051 \\
\hline RAIL & 4.3477 & 4.0176 & 0.0000 & 8.8771 \\
\hline PORT & 15.9342 & 0.7225 & 14.7466 & 17.2459 \\
\hline AIR & 11.8493 & 0.6282 & 10.8364 & 13.1576 \\
\hline
\end{tabular}

Note All variables are expressed in logs. The number of observations is 162 based on 6 countries over 17 time periods (1995-2011)

\subsubsection{Estimated Results from Spatial Panel Data Testing: Baseline}

Based on Eq. (15.1), the estimation results of the human development index as proxy for poverty reduction are shown in Table 15.2. There are six models (Model 1 to Model 6) that estimate the impacts of poverty reduction in ASEAN in the same way, but are different in the proxy explanatory variables.

The specification and diagnostic test results of all estimation models are quite similar. The Jarque-Bera test statistic indicates that the error term is normally distributed, whereas the Breusch-Pagan test statistic shows that the hypothesis of homoskedasticity is not rejected. The VIF index confirms the presence of multicollinearity in Model 1 and the absence of multicollinearity in Models 2-6. The Moran's I test statistic shows the random spatial autocorrelation in the model (very close to zero). Even though a spatial estimation model with spatially autocorrelation errors is unnecessary for estimating the model, it is still employed to examine the empirical results in this paper. In this regard, the spatial FEM and REM estimators are applied here. Moreover, Table 15.2 compares the estimated results with FEM and REM estimators for six models. In order to make better inferences, the Hausman test is taken and its statistic confirms the presence of a correlation 
15 Foreign Direct Investment and the Poverty Reduction ...

Table 15.2 Fixed effect model and random effect model of human development index as proxy for poverty reduction

\begin{tabular}{|c|c|c|c|c|c|c|}
\hline & \multicolumn{2}{|l|}{ Model 1} & \multicolumn{2}{|l|}{ Model 2} & \multicolumn{2}{|l|}{ Model 3} \\
\hline & FEM & REM & FEM & REM & FEM & REM \\
\hline \multicolumn{7}{|c|}{ Macroeconomic factors } \\
\hline GDPEMP & $-0.065 * * *$ & $0.026^{*}$ & $0.135^{*}$ & -0.011 & & \\
\hline INF & $0.017 *$ & $-0.084 *$ & $0.025^{*}$ & 0.020 & & \\
\hline RER & $-0.043 *$ & $0.214^{*}$ & 0.002 & $-0.809 *$ & & \\
\hline IEF & $0.131 * *$ & -0.007 & 0.133 & 0.006 & & \\
\hline \multicolumn{7}{|c|}{ Globalization factors } \\
\hline FDI & $-0.007 * *$ & $0.006^{*}$ & -0.008 & $-0.003^{*}$ & $-0.009 * * *$ & $0.003 *$ \\
\hline TOT & $0.004 *$ & -0.049 & 0.003 & 0.045 & $0.001 * * *$ & $-0.068 *$ \\
\hline OPEN & $0.109^{*}$ & $0.300 *$ & $0.056 * *$ & $-0.347 * *$ & $0.053 * *$ & $0.057^{*}$ \\
\hline \multicolumn{7}{|c|}{ Financial factors } \\
\hline The PRC & 0.073 & 0.001 & & & 0.025 & $0.031^{*}$ \\
\hline CAP & $-0.013 * *$ & -0.001 & & & $0.032 *$ & $0.021 *$ \\
\hline $\mathrm{CA}$ & $0.015^{*}$ & $-0.081 *$ & & & -0.001 & $-0.101 *$ \\
\hline FDEBT & $-0.047 *$ & $0.818^{*}$ & & & $-0.059 *$ & $0.265^{*}$ \\
\hline \multicolumn{7}{|c|}{ Political factors } \\
\hline GE & $0.346^{*}$ & $-0.134 * *$ & & & & \\
\hline RQ & -0.071 & $-0.433^{*}$ & & & & \\
\hline RL & $-0.493 *$ & $0.004 * *$ & & & & \\
\hline
\end{tabular}

Infrastructure factors

\begin{tabular}{|c|c|c|c|c|c|c|}
\hline ROAD & $0.003 * *$ & -0.002 & & & & \\
\hline RAIL & -0.002 & $-0.080^{*}$ & & & & \\
\hline PORT & $0.111^{*}$ & -0.008 & & & & \\
\hline AIR & -0.001 & $0.090^{* *}$ & & & & \\
\hline \multicolumn{7}{|l|}{ Spatial factors } \\
\hline WHDI & $0.091 *$ & 0.001 & $-0.126 * * *$ & $0.067 *$ & $-0.059 *$ & $-0.034 *$ \\
\hline WFDI & $0.010^{* *}$ & -0.001 & $0.034 *$ & 0.008 & $-0.303 *$ & 0.005 \\
\hline Constant & $-2.76^{*}$ & -0.034 & $-2.618^{*}$ & $0.262 *$ & $-0.831^{*}$ & -0.014 \\
\hline Spat.aut. & $-0.92^{*}$ & -0.835 & $0.645^{*}$ & $0.803^{*}$ & $0.833^{*}$ & $-0.714^{*}$ \\
\hline \multicolumn{7}{|l|}{ Goodness of fit } \\
\hline Observations & 42 & 42 & 42 & 42 & 42 & 42 \\
\hline $\operatorname{Adj} . R^{2}$ & 0.995 & 0.999 & 0.962 & 0.886 & 0.961 & 0.995 \\
\hline Log Likelihood & 126.53 & & 83.594 & & 78.961 & \\
\hline Variance $\sigma_{v}^{2}$ & 0.001 & 0.002 & 0.009 & 0.003 & 0.001 & 0.001 \\
\hline \multicolumn{7}{|l|}{ Dignostic tests } \\
\hline Jarque-Bera & $28.06^{*}$ & & $4.15 * * *$ & & 2.04 & \\
\hline VIF & 70.12 & & 8.99 & & 5.11 & \\
\hline Breusch-Pagan & $68.82 *$ & & 9.30 & & $13.89 * *$ & \\
\hline Moran's I & -0.042 & & -0.014 & & -0.015 & \\
\hline LM test & $3.48 * * *$ & & $17.24 *$ & & 0.02 & \\
\hline Hausman test & & 8.00 & & $116.01 *$ & & $305.17^{*}$ \\
\hline
\end{tabular}


Table 15.2 (continued)

\begin{tabular}{|c|c|c|c|c|c|c|}
\hline & \multicolumn{2}{|l|}{ Model 4} & \multicolumn{2}{|l|}{ Model 5} & \multicolumn{2}{|l|}{ Model 6} \\
\hline & FEM & REM & FEM & REM & FEM & REM \\
\hline \multicolumn{7}{|c|}{ Macroeconomic factors } \\
\hline GDPEMP & & & & & -0.043 & $0.018 * *$ \\
\hline INF & & & & & $0.013 *$ & 0.016 \\
\hline RER & & & & & $-0.026^{*}$ & -0.114 \\
\hline IEF & & & & & 0.062 & $-0.014 * * *$ \\
\hline \multicolumn{7}{|c|}{ Globalization factors } \\
\hline FDI & 0.002 & $-0.006^{*}$ & -0.008 & $-0.002 * *$ & $-0.008 * *$ & $0.003 *$ \\
\hline TOT & -0.001 & $0.013 * * *$ & -0.007 & -0.067 & $0.004 *$ & $-0.086 * *$ \\
\hline OPEN & $0.166^{*}$ & $0.411 *$ & $0.069 * *$ & $0.018^{*}$ & $0.149 *$ & $0.025^{*}$ \\
\hline \multicolumn{7}{|c|}{ Financial factors } \\
\hline \multicolumn{7}{|c|}{\begin{tabular}{|l|l} 
The PRC & \\
\end{tabular}} \\
\hline CAP & & & & & $-0.017 *$ & $-0.014 * *$ \\
\hline $\mathrm{CA}$ & & & & & $0.018^{*}$ & $-0.063 *$ \\
\hline FDEBT & & & & & $-0.037 *$ & $0.205^{*}$ \\
\hline \multicolumn{7}{|c|}{ Political factors } \\
\hline GE & 0.107 & $-0.567 *$ & & & $0.178 *$ & 0.043 \\
\hline RQ & -0.079 & $0.439 *$ & & & & \\
\hline RL & -0.007 & $0.331 *$ & & & $-0.511 *$ & $-0.006 * * *$ \\
\hline \multicolumn{7}{|c|}{ Infrastructure factors } \\
\hline ROAD & & & 0.003 & $0.010 * *$ & $0.002 * * *$ & $-0.141 *$ \\
\hline RAIL & & & -0.003 & $0.106 * * *$ & & \\
\hline PORT & & & $0.159 *$ & $-0.126 * *$ & $0.159 *$ & $-0.150 *$ \\
\hline AIR & & & -0.032 & $0.770 *$ & & \\
\hline \multicolumn{7}{|c|}{ Spatial factors } \\
\hline WHDI & $-0.463^{*}$ & $0.021 * * *$ & 0.055 & -0.005 & $0.070 * *$ & 0.013 \\
\hline WFDI & $0.032 * *$ & 0.002 & 0.002 & -0.002 & $0.012 * *$ & $0.432 * * *$ \\
\hline Constant & $-1.381 *$ & -0.011 & $-2.813^{*}$ & 0.001 & $-3.480^{*}$ & $0.297 *$ \\
\hline Spat.aut. & $0.802 *$ & $-0.869 *$ & $0.306^{* *}$ & $-1.035^{*}$ & $-0.854^{*}$ & 0.001 \\
\hline \multicolumn{7}{|c|}{ Goodness of fit } \\
\hline Observations & 42 & 42 & 42 & 42 & 42 & 42 \\
\hline $\operatorname{Adj} \cdot R^{2}$ & 0.915 & 0.992 & 0.952 & 0.990 & 0.994 & 0.991 \\
\hline $\begin{array}{l}\text { Log } \\
\text { Likelihood }\end{array}$ & 63.171 & & 81.218 & & 124.608 & \\
\hline Variance $\sigma_{v}^{2}$ & 0.002 & 0.003 & 0.001 & 0.005 & 0.001 & 0.007 \\
\hline \multicolumn{7}{|c|}{ Dignostic tests } \\
\hline Jarque-Bera & 0.75 & & $4.64 * * *$ & & $15.67 *$ & \\
\hline VIF & 4.71 & & 6.24 & & 25.58 & \\
\hline $\begin{array}{l}\text { Breusch- } \\
\text { Pagan }\end{array}$ & $10.26 * * *$ & & $29.81 *$ & & $49.32 *$ & \\
\hline Moran's I & -0.013 & & -0.015 & & -0.045 & \\
\hline LM test & $13.43 *$ & & 0.02 & & $3.47 * * *$ & \\
\hline Hausman test & & $410.39 *$ & & $98.33 *$ & & 8.12 \\
\hline
\end{tabular}

Note $*$, **, and $* * *$ denote the 1,5 , and $10 \%$ significance levels, respectively 
between individual effects and explanatory variables in Models 2-5, but the absence of a correlation between individual effects and explanatory variables in Models 1 and 6. The estimated results from REM are used to interpret the empirical results for Models 1 and 6.

Regarding Model 6, most estimated results are consistent with theoretical expectations and empirical findings in the poverty literature that provide support for the hypotheses of this study. In the individual-country macroeconomic parameters, the coefficient of the GDP-employment ratio is positive and significant, but the coefficient of the IEF is significant negative. It implies that an increase in $G D P$ in an individual ASEAN economy is positively related to poverty reduction in ASEAN. In the individual-country globalization parameters, the coefficient of trade balance is significant negative, while the coefficients of FDI and the degree of openness are significant positive. This suggests that an increase in FDI, trade, and economic integration in the individual ASEAN economies helps to reduce the ASEAN's poverty. In the individual-country financial parameters, the coefficients of market capitalization and current account balance are significant negative, whereas the coefficient of foreign debt is significant positive. An increase in foreign debt in the individual ASEAN economies declines the ASEAN's poverty. The coefficient of individual-country political parameter, law and order, is significant negative, and the coefficients of individual-country infrastructure parameters are significant negative. This implies that political and infrastructure development do not entirely improve the level of ASEAN's poverty. Specifically, in the spatial parameter, the coefficient of FDI is significant positive. It ensures that an increase in FDI inflows in other ASEAN economies tends to reduce poverty in the individual ASEAN countries.

In sum, inward FDI is found to cause poverty alleviation in individual ASEAN countries and an increase in ASEAN's FDI as a whole fosters a decline in poverty in this region. In other words, poverty can reduce with the spatial distribution of FDI in favor of the ASEAN economies. Moreover, ASEAN should speed up the implementation of investment liberalization agreements and other economic agreements, and the extension of economic integration to the external region in order to move up the regional value chain in ASEAN.

\subsubsection{Robustness Checks}

The robustness is to check the sensitivity of our estimated results with respect to alternative spatial-weighted schemes for third-country (spatial) effects. There are two alternative weighted schemes implemented in this study: inverse-squared bilateral distance $w_{i j}=\left(1 / d_{i j}\right)^{2} \forall i \neq j$ representing a faster spatial effect and inverse square roots of bilateral distance $w_{i j}=\left(1 / d_{i j}\right)^{1 / 2} \forall i \neq j$ representing a slower spatial effect (Baltagi et al. 2007).

The diagnostic tests and the estimated results with these alternative weighted schemes are illustrated in Table 15.3. Starting with the diagnostic tests for poverty reduction, the Moran's I test indicates the absence of spatial correlation of 


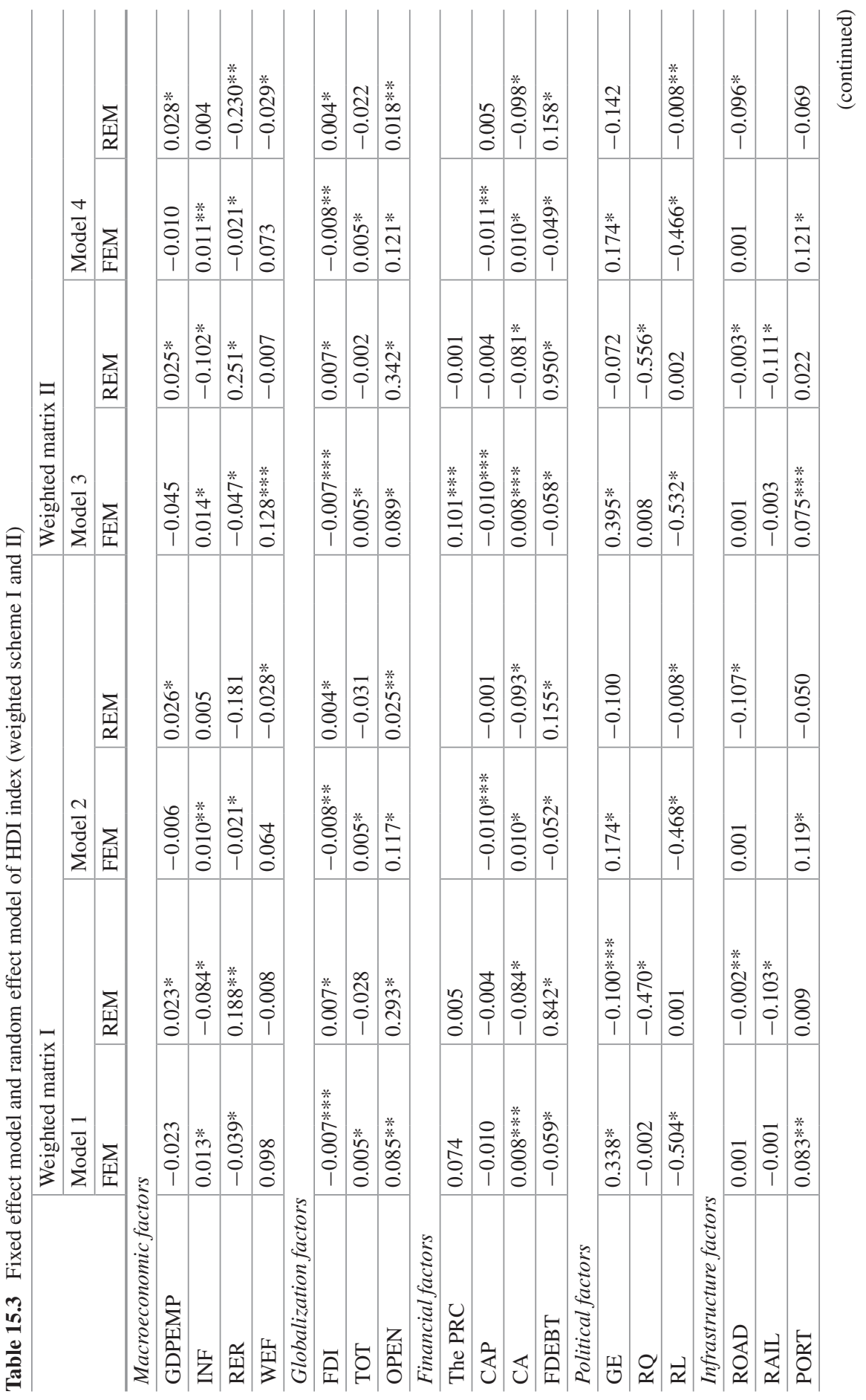


15 Foreign Direct Investment and the Poverty Reduction ...

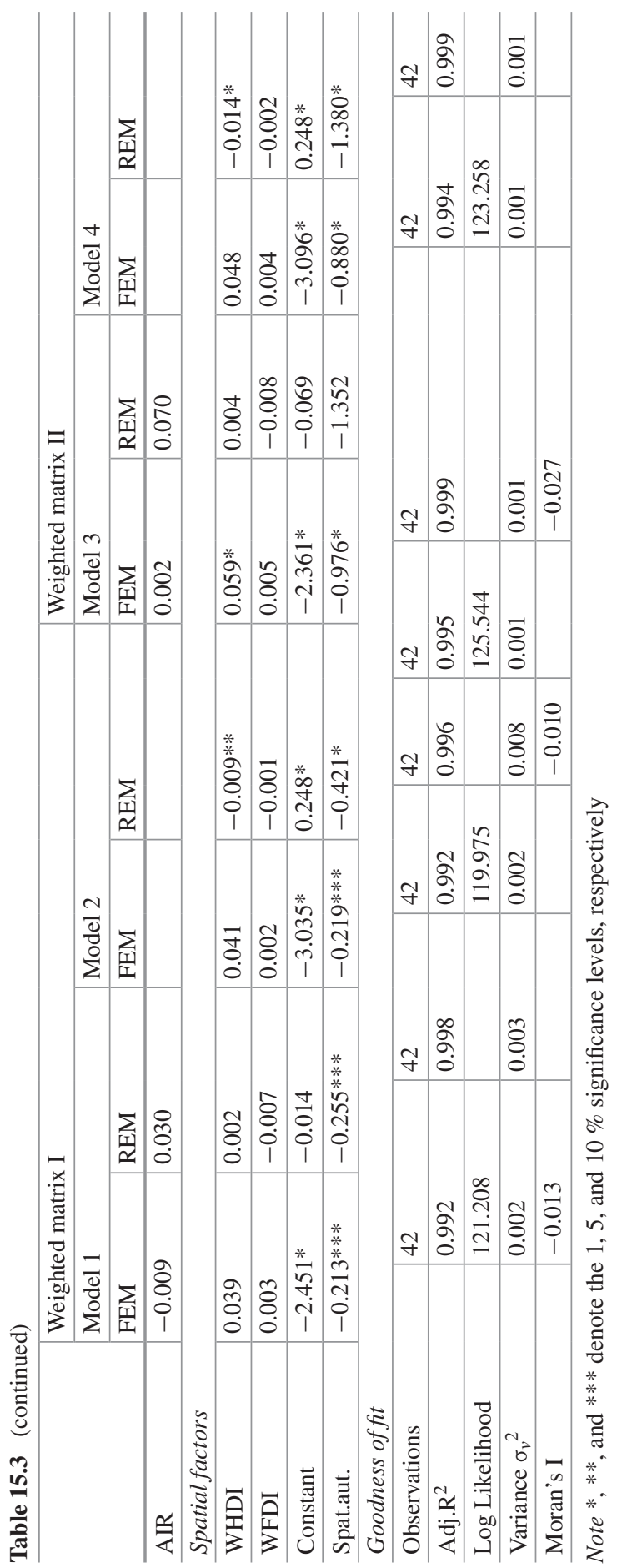


the residuals in the data as well as the baseline model. It suggests that the spatial regression model with spatially correlated residuals is not necessary to be provided. The complementary tests exhibit that the error term is normally distributed (Jarque-Bera), the hypothesis of homoscedasticity is not rejected (Breusch and Pagan), and the VIF statistic indicates no multicolinearity problems. Moreover, the empirical results illustrate that most significant explanatory variables are in line with the baseline results and the theoretical hypotheses. This implies that the estimated results are fairly robust with respect to the alternative spatial weighting schemes. In the discussion of the results, we focus on the REM estimates because the Hausman test accepts the FEM.

Specifically, in Models 2 and 4, the coefficient of individual-country FDI is significant positive, whereas the coefficient of spatial HDI parameter is significant negative. There is indeed a positive relationship between FDI and reduction poverty in ASEAN. The results also confirm that a poverty reduction in other ASEAN economies does not tend to alleviate the poverty in the individual ASEAN countries.

\subsection{Conclusion and Policy Implications}

This paper mainly focuses on the impacts of foreign FDI, related factors, and spatial effects on poverty reduction in ASEAN. The spatial panel data model techniques are employed to investigate these impacts. Data at the country level for six ASEAN economies over the period of 1995-2011 are employed. The primary estimated results reveal that bilateral FDI, economic integration, GDP, and foreign debt have significantly positive linkages with poverty reduction. In addition, the spatial effect of FDI has a positive relationship with poverty reduction. These estimated results are in line with the theoretical predictions.

Based on the results of this paper, poverty reduction in Southeast Asia is considered to be driven by FDI and economic integration. This indicates that FDI liberalization and the extension in economic integration have a significant impact on ASEAN's poverty reduction, as has been the case in other regions. To achieve the AEC goals in turning the ASEAN economies to an equitable region by 2015 , regional value chain enhancement will make the difference in creating an FDI-driven economy. The partnerships between the public and private sectors in ASEAN play an essential role to interact with the innovation to build productive capacity for regional value chain and to facilitate the joint activities across ASEAN economies to improve the human capital to make the difference in the ASEAN economic fundamentals and poverty reduction. In order to achieve these goals, the implementation of the AEC agreements should be accelerated. Moreover, the formulation and enforcement of national economic development plans need to be done well. This is what is called the FDI-poverty reduction nexus. Finally, the concept of AEC — one economic community-will become a reality if international policies on trade and investment liberalization 
and facilitation, monetary and financial security, and transportation and communication stability are integrated and harmonized into domestic policies and national economic plans.

Open Access This chapter is distributed under the terms of the Creative Commons Attribution Noncommercial License, which permits any noncommercial use, distribution, and reproduction in any medium, provided the original author(s) and source are credited.

\section{References* $^{*}$}

Adams RH Jr, Page J (2005) Do international migration and remittances reduce poverty in developing countries? World Dev 33(10):1645-1669

Akanbi OA, Du Toit CB (2011) Macro-econometric modelling for the Nigerian economy: a growth-poverty gap analysis. Econ Model 28(1-2):335-350

Anselin L (1999) Spatial econometrics. Bruton Center, University of Texas, Dallas

Anselin L (2001) Spatial Econometrics. In: Baltagi BH (ed) A companion to theoretical econometrics. Blackwell Publishing, Hoboken, pp 310-330

ASEAN Secretariat (2008) ASEAN Economic Community Blueprint. http://www.asean.org/ archive/5187-10.pdf. Accessed 15 May 2013

ASEAN Secretariat (2009) ASEAN Comprehensive Investment Agreement. http://www.asean.org/ images/2012/Economic/AIA/Agreement/ASEAN\%20Comprehensive\%20Investment\%20 Agreement\%20(ACIA)\%202012.pdf. Accessed 15 May 2013

ASEAN Secretariat (2013) ASEAN Statistics. http://www.asean.org/resources/2012-02-10-0847-55/asean-statistics. Accessed 15 May 2013

Baltagi BH, Egger P, Pfaffermayr M (2007) Estimating models of complex FDI: are there thirdcountry effects? J Econometrics 140(1):260-281

Chena A, Groenewoldb N (2013) Does investment allocation affect the inter-regional output gap in People's Republic of China? a time-series investigation. People's Republic of China Economic Review 26:197-206

Das RU (2009) Regional trade-FDI-poverty alleviation linkages some analytical and empirical explorations. Deutsches Institut für Entwicklungspolitik gGmbH

Fosu AK (2007) Poverty and development. Bull World Health Organization 85(10)

Fritzen S (2002) Growth, inequality and the future of poverty reduction in Viet Nam. J Asian Econ 13(5):635-657

Fukaoa K, Ishidod H, Itoe K (2003) Vertical intra-industry trade and foreign direct investment in East Asia. J Jpn Int Econ 17(4):468-506

Gohou G, Soumaré I (2012) Does foreign direct investment reduce poverty in Africa and are there regional differences? World Dev 40(1):75-95

Jalilian H, Weiss J (2002) Foreign direct investment and poverty in the ASEAN region. ASEAN Econ Bull 19(3):231-253

Kennedy P (2003) A guide to econometrics, 5th edn. The MIT Press, Cambridge

Kolk A, van Tulder R (2006) Poverty alleviation as business strategy? Evaluating commitments of frontrunner multinational corporations. World Dev 34(5):789-801

Nissanke M, Thorbecke E (2006) Channels and policy debate in the globalization-inequalitypoverty nexus. World Dev 34(8):1338-1360

Nissanke M, Thorbecke E (2010) Globalization, poverty, and inequality in Latin America: findings from case studies. World Dev 38(6):797-802

\footnotetext{
* ADB recognizes "China" as the People's Republic of China
} 
Ouyanga P, Fub S (2012) Economic growth, local industrial development and inter-regional spillovers from foreign direct investment: evidence from People's Republic of China. People's Republic of China Econ Rev 23:445-460

Pao H-T, Tsai C-M (2011) Multivariate Granger causality between CO2 emissions, energy consumption, FDI (foreign direct investment) and GDP (gross domestic product): Evidence from a panel of BRIC (Brazil, the Russian Federation, India, and People's Republic of China) countries. Energy 36:685-693

Reiter SL, Steensma HK (2010) Human development and foreign direct investment in developing countries: the influence of FDI policy and corruption. World Dev 38(12):1678-1691

Rezza AA (2013) FDI and pollution havens: evidence from the Norwegian manufacturing sector. Ecol Econ 90:140-149

Smarzynska BK, Wei S-J (2001) Pollution havens and foreign direct investment: dirty secret or popular myth? NBER Working paper 8465

Topalova P (2010) Factor immobility and regional impacts of trade liberalization: evidence on poverty from India. Am Econ J Appl Econ 2(4):1-41

Tsai P-L, Huang C-H (2007) Openness, growth and poverty. World Dev 35(11):1858-1871

United Nation Conference on Trade and Development (2013). Human Development Report http://hdr.undp.org/en/statistics/. Accessed 15 May 2013

Wade RH (2004) Is globalization reducing poverty and inequality? World Dev 32(4):567-589

Wooldridge JM (2001) Econometric analysis of cross section and panel data. The MIT Press, Cambridge

World Bank (2013) World Data Bank. http://databank.worldbank.org/ddp/home.do. Accessed 15 May 2013

Zaman K, Khilji BA (2013) The relationship between growth-inequality-poverty triangle and pro-poor growth policies in Pakistan: the twin disappointments. Econ Model 30:375-393 